\title{
IDENTIFIKASI AWAL POTENSI TINGGALAN BUDAYA BAWAH LAUT KALIMANTAN BARAT, BERDASARKAN DATA SIDE SCAN SONAR
}

\author{
PRELIMINARY RESEARCH OF UNDERWATER CULTURAL HERITAGES \\ IN WEST KALIMANTAN USING SIDE SCAN SONAR DATA
}

\author{
Wisnu A. Gemilang ${ }^{1}$, Nia N. H. Ridwan ${ }^{1}$, Ulung J Wisha1, Guntur A. Rahmawan ${ }^{1}$, \& Z Tahir ${ }^{2}$
}

${ }^{1}$ Loka Riset Sumber Daya dan Kerentanan Pesisir

J1 Raya Padang-Painan km.16, Bungus, Padang, Sumatera Barat-25245

${ }^{2}$ Direktorat Jasa Kelautan dan Wisata Bahari, KKP

e-mail : wisnu.gemilang@yahoo.co.id

Diterima tanggal: 8 April 209 ; diterima setelah perbaikan: 30 MAret 2020 ; Disetujui tanggal: 22 April 2020 DOI: http://dx.doi.org/10.15578/jkn.v15i1.7363

\begin{abstract}
ABSTRAK
Kalimantan Barat tidak terlepas dari sejarah perkembangan kesultanan-kesultanan Melayu dan terletak di sepanjang tepian Sungai Kapuas. Masuknya VOC sebagai kongsi dagang Belanda, semakin memperkuat jaringan perdagangan global sepanjang Sungai Kapuas. Jaringan perdagangan di kawasan Asia Tenggara menggunakan jalur utama melalui laut dan sungai, oleh karena itu tinggalan budaya bersejarah baik di darat maupun di bawah air menjadi potensi di Kalimantan Barat. Sebaran titik tinggalan budaya bawah air Kalimantan belum banyak dibuktikan dan diidentifikasi. Metode identifikasi potensi tinggalan budaya bawah air menggunakan pemetaan side scan sonar serta dikombinasi dengan model profil bawah laut dan kondisi arus sekitar lokasi dilakukan pada November 2017. Hasil side scan sonar yang dilakukan scanning sepanjang 500m setiap lokasi hanya menunjukkan 1 anomali adanya indikasi BMKT (Barang Muatan Kapal Tenggelam) di lokasi-2 dekat pulau Datu. Dimensi temuan BMKT tersebut dengan panjang kapal 15,9 meter dan lebar kapal mencapai 4,5 meter, dengan kedalaman 27-33 meter. Tingginya tingkat sedimentasi karena berada diantara muara sungai besar menjadi penyebab tertimbunnya tinggalan budaya bawah air di Kalimantan, sehingga sulit teridentifikasi. Kondisi arus yang cukup kuat menyebabkan BMKT dengan mudah bergeser atau berpindah tempat. Penelitian lebih lanjut dengan kemampuan alat berteknologi tinggi yang dapat menembus ketebalan sedimen sangat dibutukan untuk identifikasi tinggalan budaya bawah air di Kalimantan Barat.
\end{abstract}

Kata kunci: Tinggalan budaya bawah laut, Kalimantan Barat, side scan sonar, BMKT, Sungai Kapuas.

\begin{abstract}
West Kalimantan relates to Malayan Sultanates histories which located along Kapuas River. VOC entered the West Kalimantan for trading interest in which it generated the global trading in Kapuas river to become stronger. Trading web in the Southeast Asia was developed via seas and rivers. Therefore, cultural heritages both in land and underwater become resources that potentially can be developed in the West Kalimantan. Underwater cultural heritages (UCH) in Kalimantan Island and surrounding were unidentified and unproved. We used side scan sonar as an identification method to reveal the UCH combined with underwater morphological model and sea current simulation which had been done on November 2017. During SSS survey, the scanning that was elongated up to 500 meters on each site showed one anomaly indicating archaeological remains within a shipwreck. The dimension of the shipwreck reached $15.9 \mathrm{~m}$ length and $4.5 \mathrm{~m}$ width. The UCH was found between 27-33 m depth. Sedimentary regime that sources from estuaries takes place, resulting in buried UCH identified. The relatively strong currents cause material's movements that gradually fricatives into another place. Following research using hi-tech instruments that can reach sediment thickness is necessarily to be used for identifying UCH in the West Kalimantan.
\end{abstract}

Keyword: Underwater cultural heritage, West Kalimantan, side scan sonar, Kapuas river. 


\section{PENDAHULUAN}

Indonesia memiliki peninggalan arkeologi bawah air yang melimpah. Hal ini tidak terlepas dari tingginya intensitas aktifitas kelautan yang terjadi di wilayah perairan Indonesia. Sejarah budaya bahari Indonesia telah dimulai tidak kurang dari 4.500 tahun yang lalu, bersamaan dengan persebaran penutur bahasa Austronesia ke Nusantara dan Pasifik dari Pulau Formosa (Taiwan) (Mochtar, 2016). Indonesia sebagai negara maritime, memiliki kekayaan yang beranekaragam, mulai dari flora dan fauna laut hingga tinggalan budaya bawah air berupa kapal tenggelam beserta muatannya, yang dapat dimanfaatkan untuk kepentingan antara lain sektor perikanan, pariwisata dan industri kelautan (Kusumastanto, 2013). Kebudayaan masa lalu merupakan jendela yang memperlihatkan kepada kita mentalitas, kreatifitas, adat-istiadat dan tradisi budaya suatu masyarakat pada zamannya. Berbagai cara dilakukan para peneliti untuk mengungkapkan dan mempelajari benda-benda arkeologi agar memperoleh data-data yang valid (Manulu, 2013).

Potensi wisata bahari khususnya wisata selam (situs kapal tenggelam) sebagai sumber devisa berlabel industri yang menjanjikan tersebut didukung prospek wisata bahari sebagai sumber devisa oleh World Tourism and Travelling Council (WTTC) (Ardiwidjaja, 2017). Wisata bahari (wisata situs selam dan kapal tenggelam) menghasilkan devisa lebih dari US \$ 3.5 triliun atau sekitar 6-7\% dari total pendapatan kotor dunia (Honey \& Krantz, 2007). Namun pemerintah pada saat ini memiliki data dan informasi keberadaan dan profil BMKT (Barang Muatan Kapal Tenggelam) sangat minim (Ardiwidjaja, 2017). Indonesia harus memiliki kemampuan mengelola sumber daya maritime untuk kesejahteraan bangsa serta menjaga dan mencegah dari berbagai pelanggaran hukum (Muhammad, 2014).

Kenyataannya pemanfaatan yang dilakukan pemerintah hanya terfokus pada nilai ekonomis yang terkandung didalamnya sehingga eksploitasi pemanfaatan benda tersebut sebagai suatu komoditas menjadi lebih marak, baik secara legal maupun illegal. Kondisi ini tentunya akan menyebabkan hilangnya data kesejahteraan dan kebudayaan yang penting dalam merekonstruksi sejarah peradaban khususnya budaya bahari bangsa Indonesia (Ardiwidjaja, 2017). Kapal tenggelam atau shipwreck beserta benda berharga muatannya merupakan kapal kuno yang tenggelam sebelum abad ke-20 hingga masa Perang Dunia II. Jumlah kapal tenggelam di perairan Indonesia diperkirakan mencapai hingga ribuan kapal (Mundardjito, 2007).

Proses pembentukan kota-kota di Kalimantan Barat, Indonesia tidak terlepas dari sejarah perkembangan kesultanan-kesultanan Melayu. Keberadaan sungai Kapuas sebagai jalur transportasi dan komunikasi semakin penting ketika perdagangan global merambah wilayah-wilayah kesultanan dengan potensi alamnya masing-masing (Andi, 2017). Kalimantan Barat merupakan salah satu provinsi yang belum tergali secara optimal benda arkeologinya. Beberapa tahun terakhir banyak penemuan-penemuan arkeologi, seperti pada tahun 2010 di temukan sebuah Candi di Ketapang yang diduga merupakan Candi Budha, mengingat belum adanya candi Budha yang ditemukan di Pulau Kalimantan (Manalu, 2013). Penelitian terhadap potensi arkeologi Kalimantan Barat hanya terkonsentrasi pada peninggalan budaya di darat, belum menuju penelitian tinggalan budaya bawah air Kalimantan Barat.

Inventarisasi yang dilakukan oleh Departemen Kelautan dan Perikanan terdapat 463 lokasi kapal tenggelam antara tahun 1508 sampai dengan 1878 yang tersebar di perairan Indonesia. Begitu pentingnya tinggalan arkeologi dibawah air sebagai data dan informasi rekonstruksi sejarah budaya Indonesia sehingga arkeologi bawah air tidak dapat dipandang sebelah mata (Sofian, 2010). Pencarian benda-benda tinggalan budaya bawah air membutuhkan peralatan pendukung yang dapat dioperasikan di bawah air seperti peralatan GPS (Global Positioning System), ROV (Remotely Operated Vehicles), Magnetometer dan Acoustic System. Peralatan yang sering digunakan untuk pendeteksian awal keberadaan benda tinggalan budaya bawah air yaitu acoustic system yang merupakan peralatan pendeteksian yang menggunakan gelombang suara untuk mendeteksi anomaly lingkungan dibawah air seperti alat Side Scan Sonar (Green, 2004).

Survei geofisika, khususnya metode sonar, telah digunakan dalam penyelidikan situs arkeologi bawah laut selama beberapa dekade, tetapi sebagian besar pekerjaan terfokus pada menemukan dan mencirikan situs kapal karam (Sonnenburg \& Joseph 2008). Upaya mengidentifikasi barang-barang tinggalan sejarah di perairan Kalimantan Barat sangat dibutuhkan terutama barang peninggalan bersejarah bawah laut. Selain itu belum banyak dilakukan penelitian terkait barang peninggalan bersejarah bawah laut di Kalimantan Barat. Penelitian ini bertujuan untuk mengidentifikasi 
arkeologi bawah laut Kalimantan Barat sehingga dapat diketahui sebaran lokasi titik arkeologi bawah laut khusunya di perairan sekitar muara Sungai Kapuas.

\section{BAHAN DAN METODE}

P Kegiatan pemetaan bawah laut dalam upaya verifikasi keberadaan BMKT di sekitar perairan Kalimantan Barat dilakukan selama 2 (dua) hari pengukuran yaitu pada tanggal 15-16 November 2017. Lokasi target pemetaan dan verifikasi dilakukan pada 2 (dua) area di Kabupaten Mempawah yang telah disepakati dengan beberapa pertimbangan. Pertimbangan penentuan lokasi merupakan hasil informasi dari penyelam lokal terkait keberadaan situs kapal tenggelam pada 2 lokasi tersebut, selain itu juga berdasarkan pada kesampaian lokasi menuju titik pengamatan yang tidak terlalu jauh dari pangkalan PSDKP Pontianak. Beberapa pertimbangan itulah penentuan 2 area verifikasi dilakukan. Pada Gambar 1 memperlihakan lokasi pengukuran pertama berada tidak terlalu jauh dari muara Sungai Jungkat dengan jarak 17,42 mil laut. Lokasi kedua berada cukup jauh dari muara sungai, yaitu dekat dengan Pulau Datu, dengan jarak 46,93 mil laut dari muara sungai.

Identifikasi terhadap keberadaan situs arkeologi bawah laut Kalimantan Barat menggunakan peralatan geofisika akustik bawah air. Peralatan geofisika akustik bawah air yang digunakan terdiri dari dua alat utama yaitu Starfish 452F Side Scan Sonar (SSS) dan Echosounder Hi-Sounder HD-380 (Gambar 2). Side Scan Sonar

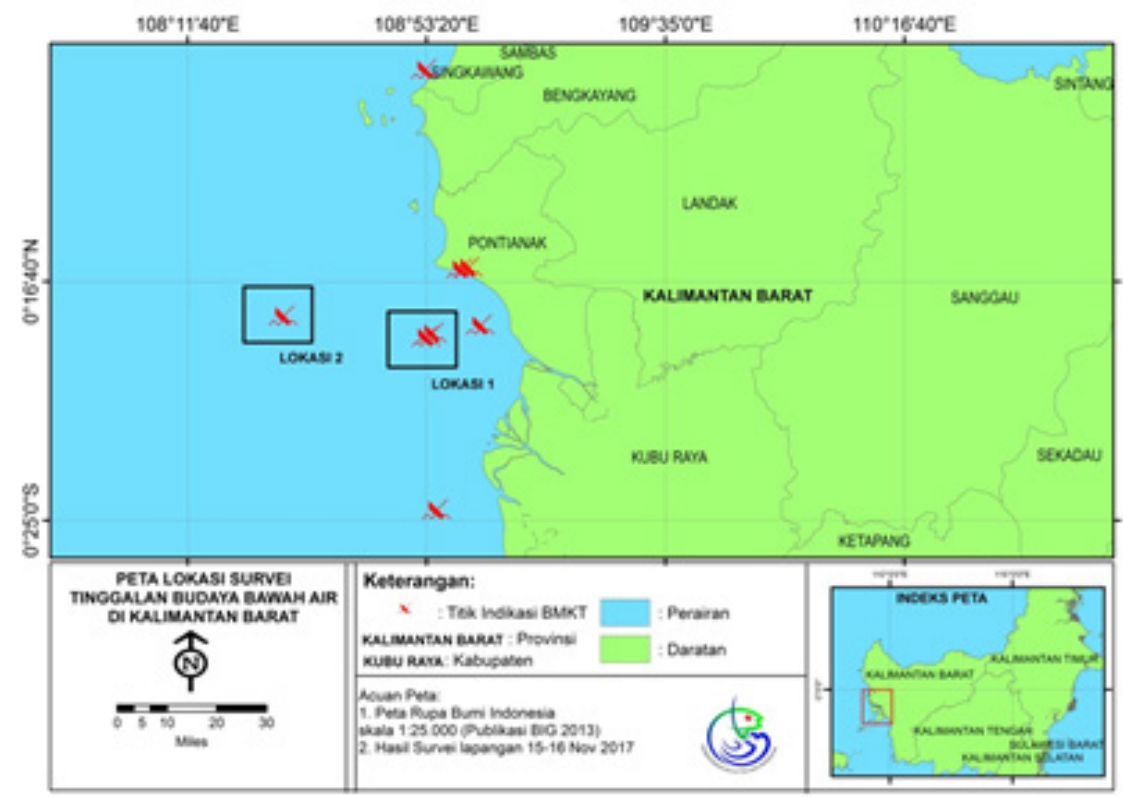

Gambar 1. Peta lokasi survei di perairan Kalimantan Barat.

Figure 1. Map of survey locations in the waters of West Kalimantan.

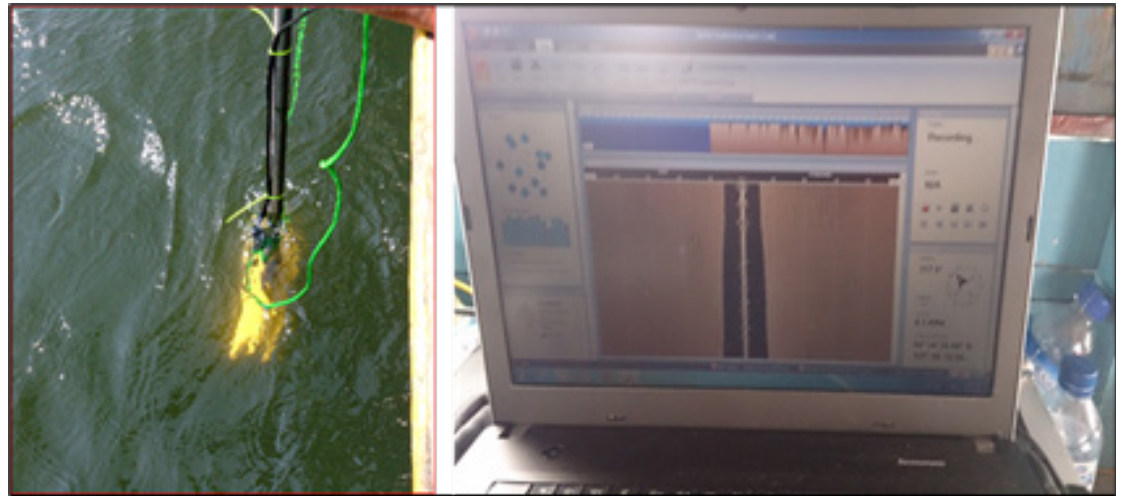

Gambar 2. Tranduser sebagai source dan receiver gelombang akustik (gambar kiri); citra dasar laut teramati secara real-time dalam monitor di atas kapal (gambar kanan). (Sumber: hasil survei 2017)

Figure 2. Transducer as source and acoustic wave receiver (left picture); Seafloor images are observed in real-time on a monitor on board (right picture). (Source: 2017 survey results) 
digunakan untuk mengetahui gambaran atau citra dasar laut di area survei. Sistem perekamaannya pada dasarnya sama dengan sistem perekaman echosounder dimana tranduser yang berfungsi ganda sebagai source maupun receiver dan dipasang pada kedalaman 1 meter dibawah permukaan air laut atau dapat juga di towing seperti seismic. Pada kegiatan survei, alat SSS dipasang dengan cara ditempelkan oleh besi disamping kapal survei untuk menghindari tersangkut oleh batuan atau terumbu yang berada di bawah air laut.

Gelombang suara yang digunakan pada SSS tersebut mempunyai frekuensi mid-band $450 \mathrm{kHz}$ CHIRP yang merupakan gabungan antara kemampuan deteksi dan resolusi. SSS Starfish banyak digunakan untuk penelitian geofisika kelautan karena dapat memetakan dasar laut, medeteksi dan mencari jalur kabel, pipa laut, kapal karam dan obyek-obyek bawah air lainnya. Menurut (Gron et al., 2015), metodologi akustik bawah air sangat bagus dalam menggambarkan struktur kapal karam dan memetakan morfologi dasar laut pada lingkungan situs. Selain menggunakan alat instrumen geofisika dilakukan juga verifikasi data bawah air dengan membuat peta batimetri berdasarkan data sekunder citra SRTM (Shuttle Radar Topography Mission) profil bawah laut untuk mengetahui profil kedalam lokasi penelitian. Pemodelan kondisi hidrodinamika juga dilakukan sehingga kondisi hidrooseanografi sekitar lokasi indikasi temuan tinggalan budaya bawah air dapat diketahui. Secara garis besar tahapan dari pengolahan data yang dilakukan adalah

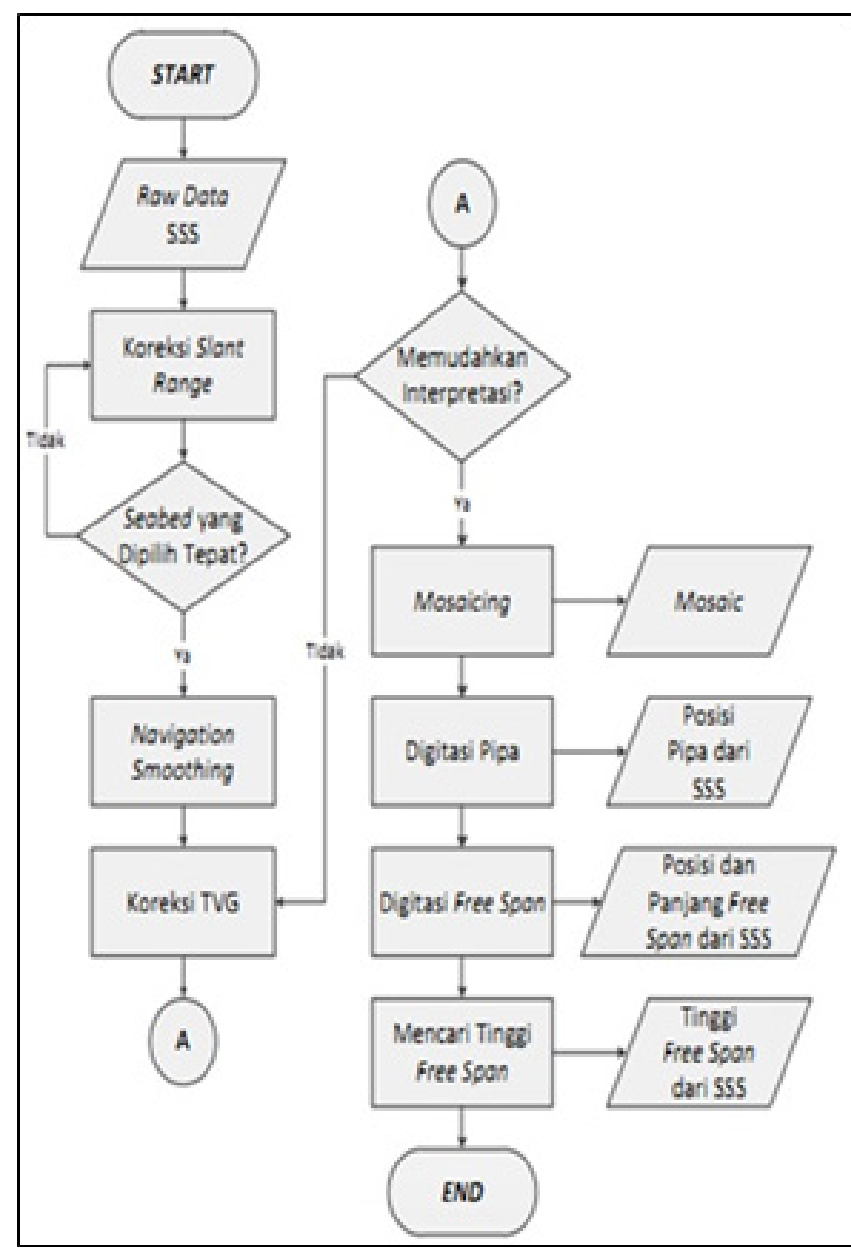

Gambar 3. Diagram alir pengolahan data SSS. Figure 3. SSS data processing flowchart.

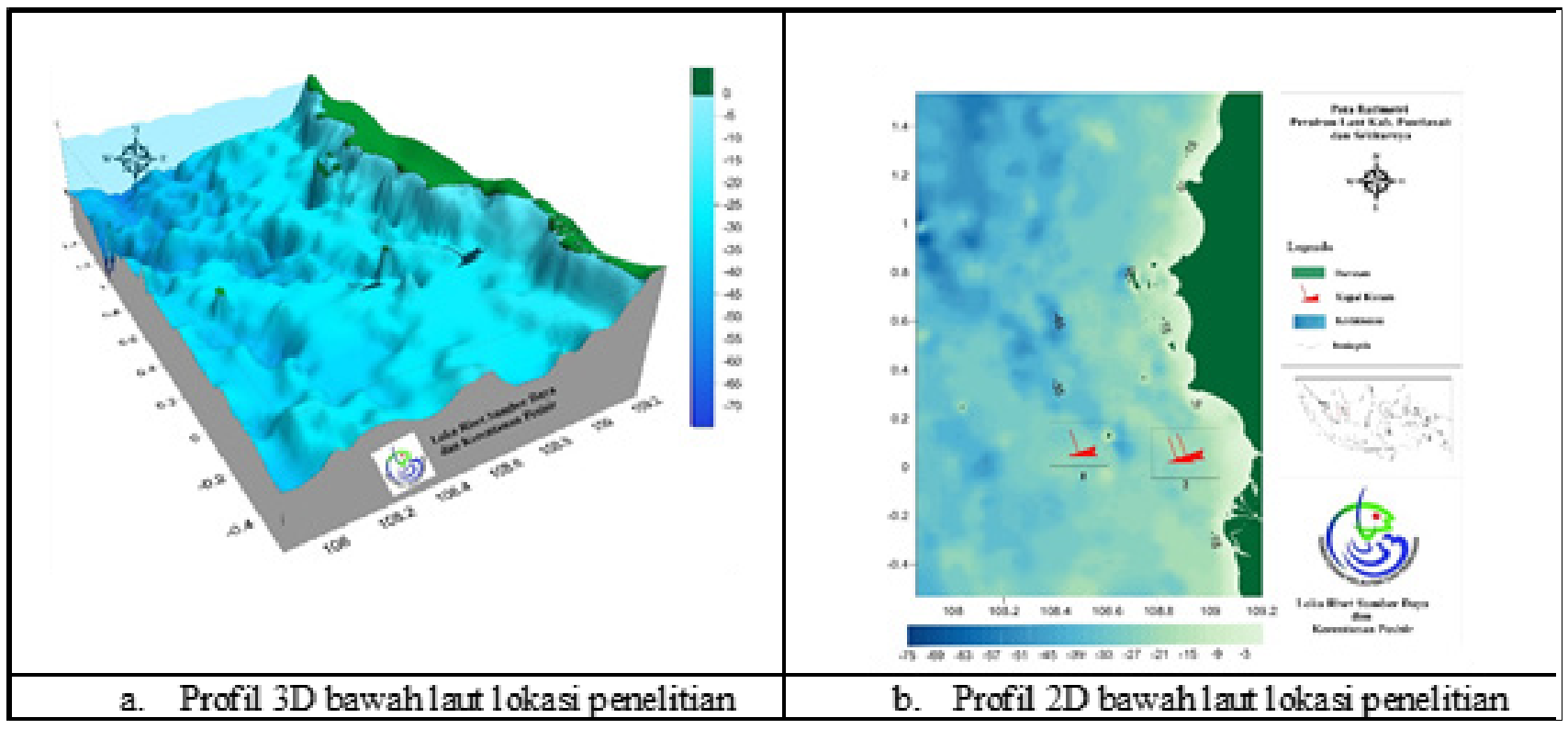

Gambar 4. Profil bawah laut lokasi penelitian.

Gambar 4. Underwater profile of the study site. 
seperti pada Gambar 3.

\section{HASIL DAN PEMBAHASAN}

\section{Profil Bawah Laut Kalimantan Barat}

Perairan laut Kalimantan Barat merupakan daerah yang memiliki batimetri laut yang relatif dangkal dan datar. Gradient kemiringan dasar perairan kurang dari $30 \%$ dengan karakteristik perairan yang agak keruh. Karakteristik wilayah daratan yang banyak memiliki muara sungai, maka wilayah perairan laut ini dangkal dan memiliki kekeruhan yang tinggi, kadar garam yang rendah, dan bahan organik yang cukup tinggi (Sugito et al, 2018). Bentuk garis kontur kedalaman mengikuti bentuk garis pantai. Semakin jauh dari garis pantai, nilai kontur kedalaman semakin besar (semakin dalam). Rentang kedalaman wilayah studi rata-rata berkisar dari kedalaman $1 \mathrm{~m}-50 \mathrm{~m}$. Kedalaman tersebut bertambah ke arah barat dan barat daya yaitu berkisar antara 10 hingga 45 meter. Hasil peta batimetri terhadap titik 2 lokasi dugaan BMKT berada pada kedalaman 27-33m dengan jarak 18,51 miles dan 20,05 miles dari muara sungai (Gambar 4). Morfologi dasar laut bervariasi dari kemiringan relatif landai hingga curam.

Muara Sungai Kapuas dan perairan pantai sekitar muara merupakan alur pelayaran yang sering mengalami pendangkalan yang membahayakan kapal-kapal yang melaluinya. Pendangkalan ini terjadi akibat adanya pengendapan material sedimen (Nurdiati et al., 2016). Rata-rata laju sedimen di Muara Jungkat sebesar 2,1093 $\mathrm{cm} /$ tahun dan Sungai Kapuas Kecil sebesar 1,1747 cm/ tahun. Hal ini menunjukkan laju sedimentasi di Muara Jungkat lebih besar sehingga akan terjadi penumpukan sedimen di muara sungai dan sekitarnya (Sa'adah et al., 2015).

Tingginya sedimentasi di lokasi BMKT dapat berpotensi dalam peningkatan potensi korosi pada besi kapal dan muatannya, selain itu sedimentasi yang cukup tinggi juga dapat menyebabkan tinggalan arkeologis di muara Sungai Kapuas terpendam oleh sedimen bila tidak dilakukan tindakan preservasi. Dua lokasi dugaan BMKT berada tidak terlalu jauh dengan muara sungai Kapuas kecil dan Muara Jungkat, sehingga terlihat jelas pada profil 3D batimetri memperlihatkan morfologi bergelombang, hal tersebut dipengaruhi oleh kondisi pengendapan sedimen dari muara sungai yang tidak stabil serta dipengaruhi kondisi arus sekitar lokasi.

Identifikasi BMKT menggunakan Side Scan Sonar Kegiatan verifikasi BMKT dengan pemetaan menggunakan peralatan side scan sonar di perairan Pontianak, Kalimantan Barat dilakukan di 3 (tiga) titik lokasi. Sejumlah 2 (dua) titik lokasi pengamatan dan pengukuran SSS dari sebanyak sebaran titik dugaan BMKT yanga da di perairan Kalimanta Barat (Gambar 5). Lokasi pengamatan dan pengukuran dengan SSS berada dekat dengan muara, dan 1 lokasi lagi berada cukup jauh dari muara sungai (Gambar 1).

Lokasi pengukuran side scan sonar pertama di perairan Kalimantan Barat, berada 18,51 mil dari muara sungai Kapuas, sehingga lokasi pengamatan tersebut banyak dipengaruhi oleh aktifitas sungai. Saat pelaksanaan kegiatan pengumpulan data di lapangan, kondisi perairan cukup keruh dimana tingkat kekeruhan sangat dipengaruhi oleh asupan sedimen melayang dari sungai. Selain itu, muara Sungai Kapuas juga memiliki karakteristik gelombang dan kecepatan arus laut yang cukup tinggi. Hasil pemetaan side scan sonar pada lokasi 1 memperlihatkan banyaknya noise (gelombang gangguan) yang dikarenakan pada saat pengukuran kondisi perairan sangat bergelombang sehingga kapal tidak dapat stabil bergerak (Gambar 6). Hasil side scan sonar pada lokasi-1 tidak memperlihatkan adanya gejala keberadaan BMKT pada lokasi tersebut. Hal tersebut dapat dikarenakan tingginya tingkat laju sedimentasi pada lokasi-1 sehingga keberadaan BMKT tidak dapat terdeteksi oleh side scan sonar.

Relief yang ditunjukkan pada hasil side scan sonar cenderung berelief halus, sehingga dapat diinterpretasikan bahwa sedimen dasar perairan pada lokasi-1 memiliki tekstur halus seperti pasir sangat halus hingga lanau. Jenis substrat sedimen dasar perairan sekitar Muara Jungkat dan Kapuas kecil berjenis pasir lanauan (silty sand), lanau pasiran (sandy silt) dan lanau (silt) (Sa'adah et al., 2015). Kondisi BMKT yang tidak terlihat pada lokasi-1 juga kemungkinan disebabkan adanya penumpukan ketebalan sedimen, karena posisi yang dekat dengan muara sungai. Pada saat air sungai bertemu dengan arus pasang di muara sungai, sehingga akan terjadi penumpukan sedimen di sekitar muara sungai. Penumpukan massa air ketika arus pasang bertemu dengan air air sungai menuju hilir (Gemilang et al, 2018). Aliran sepanjang sungai sebagai dampaknya sungai membawa material sedimen dan limbah yang berasal dari hulu dan sepanjang aliran sungai yang akan diendapkan di sekitar muara sungai, sehingga keberadaan BMKT akan sulit ditemukan.

Lokasi pengukuran ke-2 (M-06) yang berada cukup jauh dari muara sungai $(48,66$ mil). Kondisi perairan pada lokasi ini tidak terlalu keruh dengan tingkat 


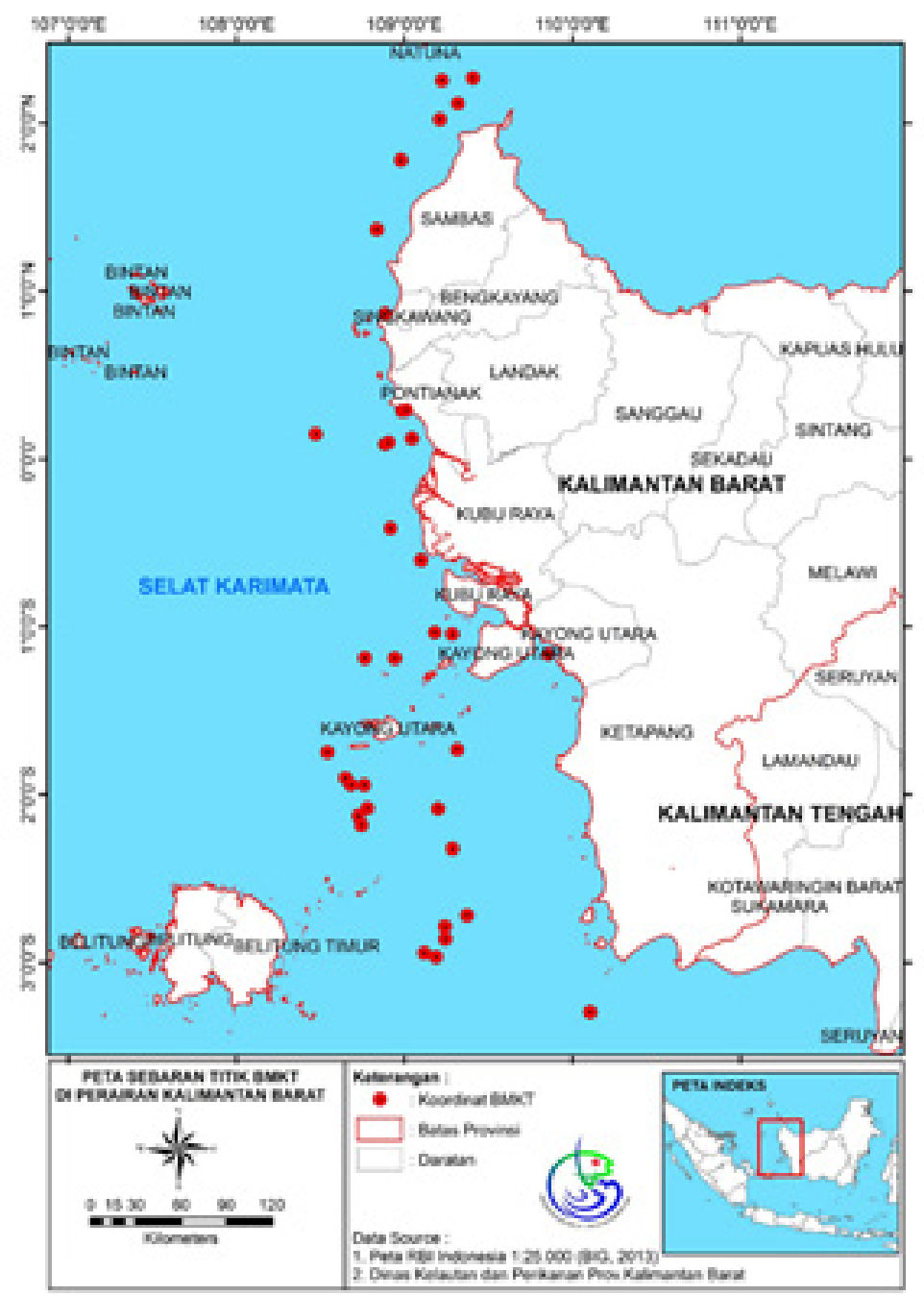

Gambar 5. Peta sebaran titik dugaan BMKT (Barang Muatan Kapal Tenggelam) di perairan Kalimantan Barat Gambar 5. Map of alleged distribution points of BMKT (Freight Ship Sinking) in the waters of West Kalimantan.

visibilitas yang cukup baik., selain itu pada wilayah tersebut juga merupakan area pemancingan bagi para wisatawan (sekitar Pulau Datu) (Gambar 1). Pulau Datu merupakan salah satu pulau wisata di Kalimantan Barat, selain wisata pantai, pulau tersebut juga memiliki banyak aneka ragaman ikan. Hasil dari pemetaan menggunakan side scan sonar, menunjukkan adanya indikasi keberadaan kapal tenggelam pada lokasi ke-2 (Gambar 6). Dimensi kapal yang terekam oleh hasil pengukuran SSS yaitu panjang kapal 15,9 meter dan lebar kapal mencapai 4,5 meter. Relief hasil side scan sonar memperlihatkan rona yang halus sehingga dapat dikatakan substrat sedimen dasar perairan lokasi-2 berjenis sediman pasir halus hingga lanau.

Hasil side scan sonar baik pada lokasi-1 maupun 2 tidak memperlihatkan rona atau relief kasar, sehingga dapat diinterpretasikan area penelitian tidak ditumbuhi oleh terumbu karang. Terumbu karang yang relatif tinggi, dapat diidentifkasi dengan bayangan terumbu yang terlihat pada hasil rekaman (Anitha et al., 2016). Semakin tinggi terumbu karang yang tumbuh, bayangannya pun semakin kuat, sebagai hasil refleksi sinar yang terhalang oleh terumbu karang tersebut.

\section{Pengaruh Kondisi Hidro-Oseanografi Terhadap Keberadaan BMKT}

Pada kondisi pasang purnama, kecepatan arus berkisar antara $0-0,32 \mathrm{~m} / \mathrm{s}$ dengan dominasi arah arus menuju ke barat (Gambar 8). Di sekitar lokasi BMKT kecepatan arus berkisar antara $0,07-0,18 \mathrm{~m} / \mathrm{s}$. sedangkan pada kondisi surut purnama, kecepatan arus berkisar antara $0-0,20 \mathrm{~m} / \mathrm{s}$ dengan dominasi arah arus bergerak ke utara, timur, dan selatan (Gambar 8). Wilayah perairan dimana BMKT berada merupakan perairan dangkal dan termasuk daerah pengaruh angin, sehingga saat elevasi 


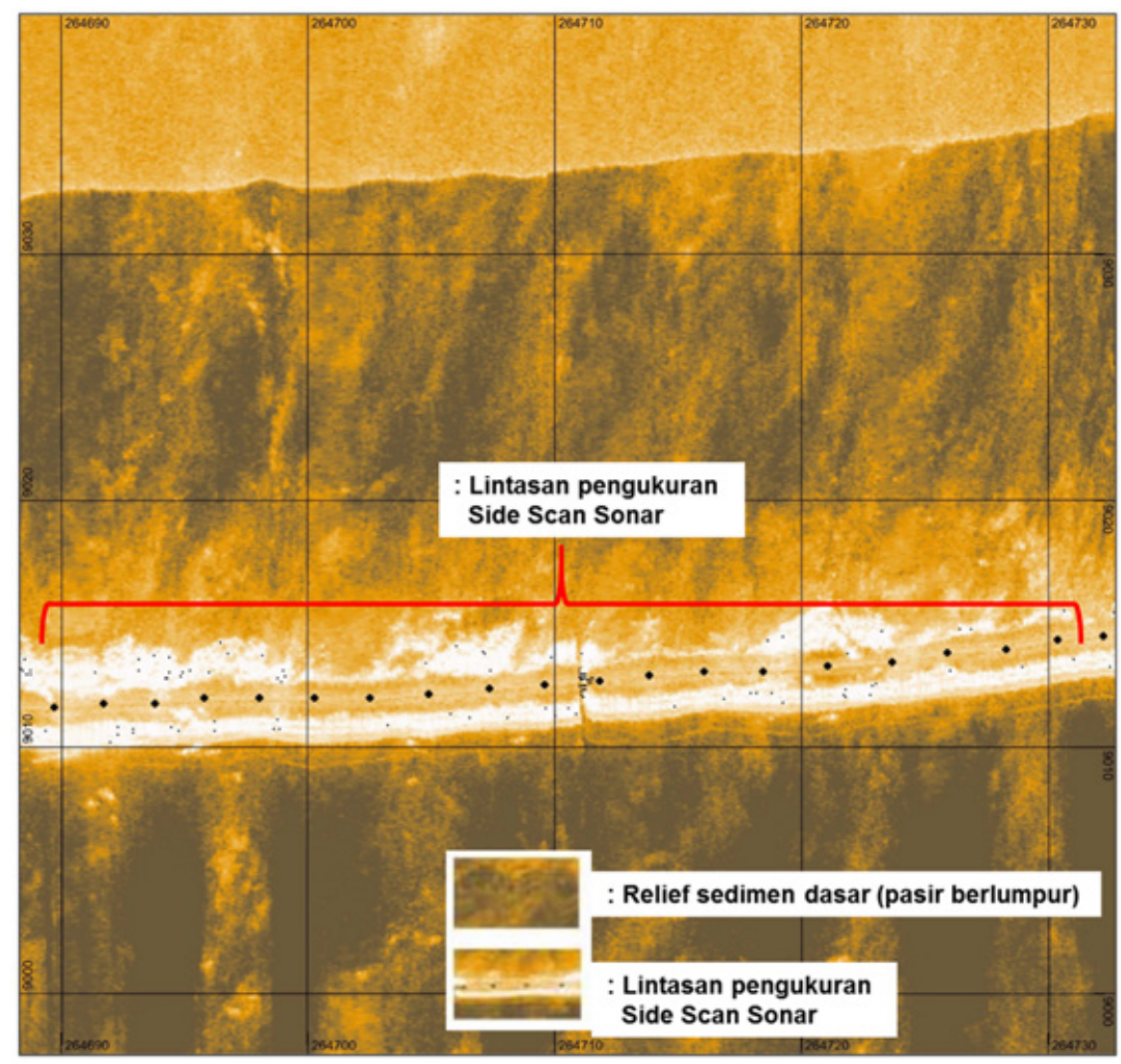

Gambar 6. Peta hasil pemetaan side scan sonar pada lokasi-1. Gambar 6. Map of the results of side scan sonar mapping at location-1.

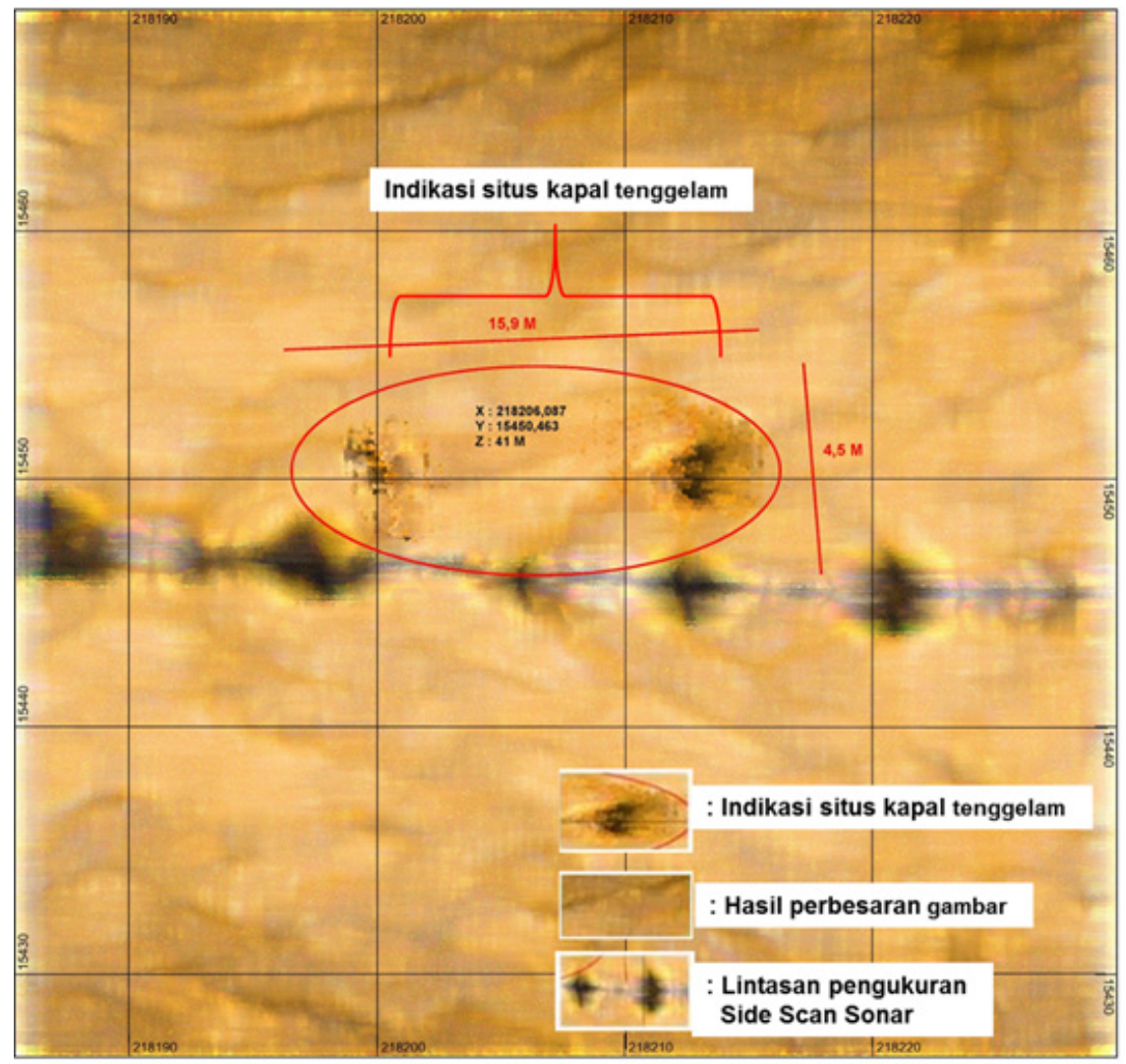

Gambar 7. Peta hasil pemetaan side scan sonar pada lokasi-2.

Gambar 7. Map of the results of side scan sonar mapping at location-2.

$\overline{\text { Identifikasi Awal Potensi Tinggalan Budaya Bawah Laut Kalimantan Barat, Berdasarkan Data Side Scan Sonar - Wisnu A. }}$ Gemilang, Nia N. H. Ridwan1, Ulung J Wisha, Guntur A. Rahmawan, \& Z Tahir 
muka laut mencapai titik maksimalnya, maka tinggi gelombang dan kecepatan arus semakin meningkat (Agustini et al., 2016). Profil dasar perairan yang tidak stabil menghasilkan profil arus yang tidak stabil pada kedua lokasi situs BMKT dimana kecepatan arus lebih tinggi pada situs di dekat Pulau Datu.

Pada kondisi perbani, kecepatan arus lebih lemah daripada kondisi purnama. Pada kondisi pasang perbani kecepatan arus berkisar antara, $0-0.10 \mathrm{~m} / \mathrm{s}$ dan pada saat surut perbani kecepatan arus berkisar antara $0-0,13 \mathrm{~m} / \mathrm{s}$ (Gambar 8). Dominasi arah pergerakan arus dominan ke arah timur saat pasang dan ke arah barat saat surut. Kecepatan arus saat surut perbani lebih tinggi daripada saat pasang, hal ini mengindikasikan bahwa mekanisme transpor sedimen lebih maksimal terjadi saat surut perbani (Aryani et al., 2016). Perairan
Kalimantan Barat sangat identik dengan tingkat sedimentasi yang tinggi sebagai akibat dari keberadaan Sungai Kapuas yang menjadi sumber utama sedimen ke perairan.

Masalah sedimentasi menjadi salah satu faktor ancaman terhadap situs BMKT di Kalimantan Barat, dengan adanya dukungan dinamika arus laut menyebabkan penutupan situs BMKT oleh sedimen yang mana kecepatan arus yang tinggi berpotensi menyebabkan mekanisme turbulensi di bibir pantai, dan pada saat-saat tertentu, kecepatan arus menjadi lemah, maka sedimen melayang akan mulai mengendap di dasar perairan, hal ini dapat mengancam kelestarian situs BMKT. Selain itu karena letaknya yang berada di wilayah Selat Karimata, arus yang cukup kuat menyebabkan BMKT dengan mudah bergeser atau berpindah tempat. Menurut

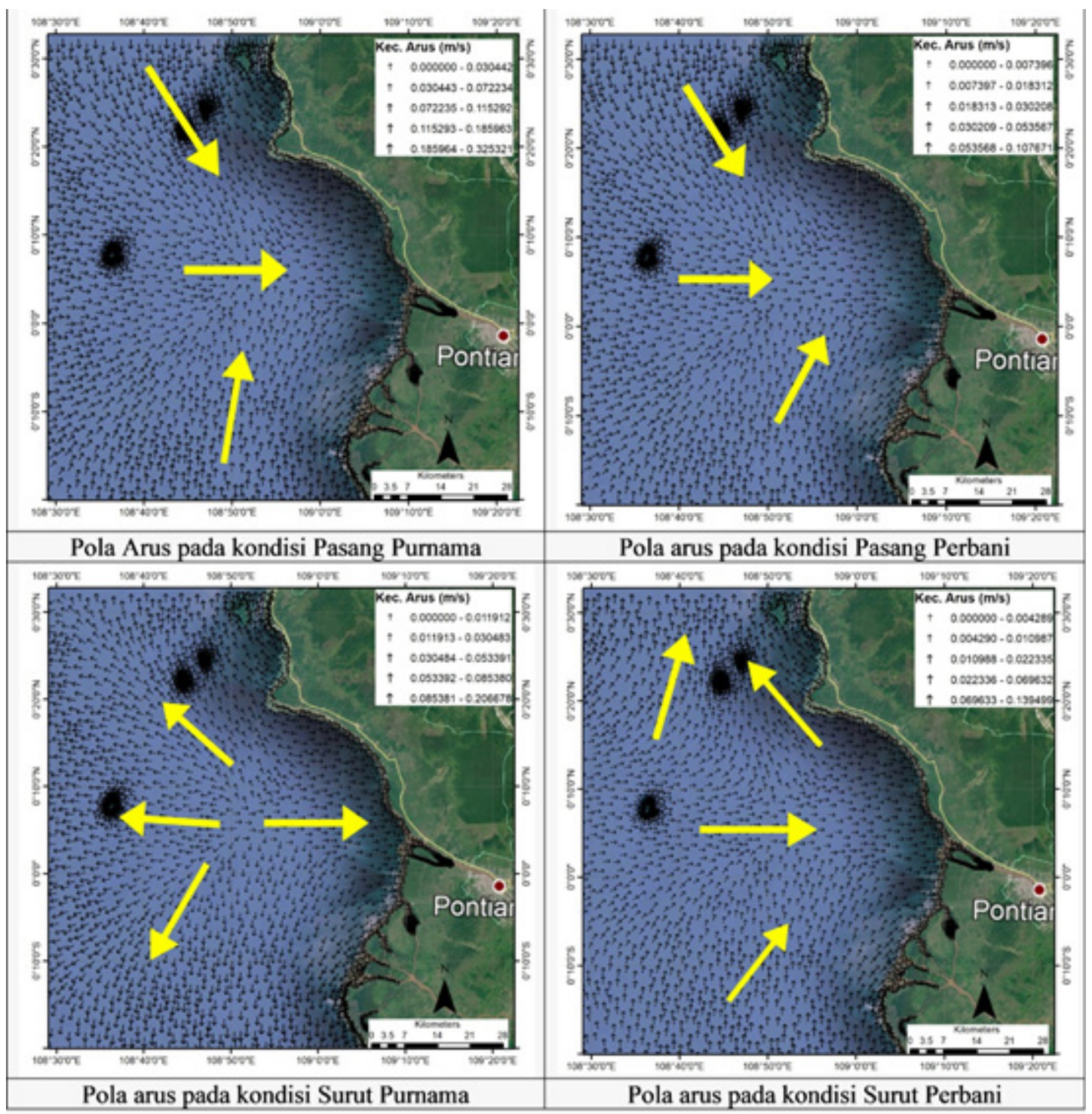

Gambar 8. Pola arus pasang surut di sekitar situs

Figure 8. Tidal current patterns around the site. 
Heriati et al. (2015) kecepatan arus di Selat Karimata cukup kuat dan berkisar antara $0,3-0,6 \mathrm{~m} / \mathrm{s}$ yang terjadi pada kondisi pasang menuju surut purnama. Sehingga sangat disarankan untuk melakukan ekskavasi yaitu pengangkatan BMKT dari timbunan sedimen agar BMKT yang ada dapat dilestarikan dan menjadi sumber sejarah yang sangat penting bagi perkembangan ilmu pengetahuan.

Lokasi BMKT yang berada didaerah pengaruh pasang surut menyebabkan pada saat-saat tertentu, kekeruhan perairan menjadi meningkat. Maka sangat disarankan sebelum melakukan eskavasi perlu untuk memprediksi pasang surut, terutama saat kondisi pasang dimana perairan cenderung lebih jernih (Suandi et al., 2016).

\section{KESIMPULAN DAN SARAN}

Hasil identifikasi terhadap 2 (dua) titik sebaran BMKT yang ada di perairan Kalimantan Barat menggunakan side scan sonar, hanya terlihat adanya gejala keberadaan BMKT di lokasi ke-2. Beberapa faktor yang menyebabkan sulitnya terdeteksi dan pembuktian terhadap beberapa BMKT adalah tingginya tingkat sedimentasi perairan karena pengaruh keberadaan muara sungai Kapuas dan anak-anak sungainya. Selain itu, kondisi hidrodinamika pada area situs memiliki peran besar terhadap kelestraian BMKT dimana mekanisme pengadukan dan pengendapan yang cukup tinggi serta kondisi arus kuat dapat menyebabkan kerusakan dan perpindahan posisi BMKT. Aliran massa air di Selat Karimata menyebabkan kondisi arus sekitar BMKT menjadi cukup kuat dan menyebabkan BMKT dengan mudah bergeser atau berpindah tempat. Dibutuhkan penelitian lebih lanjut dengan peralatan yang lebih detail yang dapat menembus ketebalan sedimen

\section{UCAPAN TERIMA KASIH}

Penulis menyampaikan terima kasih kepada Ditjen Jasa Kelautan, Direktorat Jenderal Pengelolaan Ruang Laut dan segenap peneliti dari Loka Riset Sumber Daya dan Kerentanan Pesisir (LRSDKP), BRSDMKP yang telah bersama-sama melaksanakan kegiatan survei terintegrasi terhadap situs tinggalan budaya bawah air di perairan Kalimantan Barat. Tak lupa penulis juga mengucapkan terimakasih kepada DKP Provinsi Kalimantan Barat, kelompok penyelam lokal Pontianak yang telah membantu dalam proses pengambilan data di lapangan.

\section{DAFTAR PUSTAKA}

Andi, U. F. (2017). Pengaruh Jaringan Perdagangan Global Pada Struktur Wilayah Dan Konfigurasi Spasial Pusat Pemerintahan Kesultanan-Kesultanan Melayu Di Kalimantan Barat. Langkau Betang: Jurnal Arsitektur, 4(1), 67-78.

Anitha, U., Malarkkan, S., Premalatha, J., \& Prince, P. G. K. (2016). Study of Object Detection in Sonar Image using Image Segmentation and Edge Detection Methods. Indian Journal of Science and Technology, 9(42).

Ardiwidjaja, R. (2017). Pelestarian Tinggalan Budaya Bawah Air: Pemanfaatan Kapal Karam sebagai Daya Tarik Wisata Selam. AMERTA, 35(2), 133-148.

Aryani, R., Saputro, S., \& Hariadi, H. (2016). Sebaran Material Padatan Tersuspensi Berdasarkan Pengaruh Arus Dan Pasang Surut Di Sekitar Perairan Muara Sungai Kapuas Kecil, Jungkat, Pontianak. Journal of Oceanography, 5(4), 470-478.

Gemilang, W. A., Wisha, U. J., \& Rahmawan, G. A. (2018). Particle Size Characteristics Of Riverbed Sediment Transported By Tidal Bore" Bono"(Case Study: Kampar Big River Estuary, Riau, Indonesia). Marine Research in Indonesia, 43(1).

Green, J. (2004). Maritime archaeology A Technnical Handbook (Second Edition). United Kingdom. Elsevier Acdemic Press.

Grøn, O., Boldreel, L. O., Cvikel, D., Kahanov, Y., Galili, E., Hermand, J. P., ... \& Reitan, M. (2015). Detection and mapping of shipwrecks embedded in sea-floor sediments. Journal of Archaeological Science: Reports, 4, 242-251.

Heriati, A., Mustikasari, E., \& Al Azhar, M. (2015). Variabilitas Pola Arus dan Gelombang di Selat Karimata. Jurnal Segara, 11(2), 125-136.

Kusumastanto, T. (2013). Arah Strategi Pembangunan Indonesia Sebagai Negara Maritim. Researchgate. Accessed July, 20, 2017. https://scholar.google.co.id/ scholar?hl=en\&as_sdt $=0 \% 2 \mathrm{C} 5 \& \mathrm{q}=\mathrm{Arah}+$ Strategi $+\mathrm{P}$ embangunan+Indonesia+Sebagai+Negara+Maritim $\& b \operatorname{tnG}=$.

Manalu, B. Pusat Kajian dan Penelitian Arkeologi Kalimantan Barat. Jurnal Online Mahasiswa S1 Arsitektur UNTAN, 1(2).

Mochtar, A. S. (2016). In-situ Preservation Sebagai Strategi Pengelolaan Peninggalan Arkeologi Bawah Air Indonesia. KALPATARU, 25(1), 53-64.

Muhamad, Simele Victor. (2014). Indonesia Menuju Poros Maritim Dunia. Info Singkat Hubungan I: 5-8.

Mundardjito, M. (2007). Paradigma dalam Arkeologi Maritim. Wacana, 9(1), 1-20.

Nurdianti, A. K., Atmodjo, W., \& Saputro, S. (2016). Studi Batimetri Dan Kondisi Alur Pelayaran Di Muara Sungai Kapuas Kecil, Kalimantan Barat. Journal of Oceanography, 5(4), 538-545.

Sa'adah, N., Subardjo, P., Atmodjo, W., \& Ismail, M. F. A. (2015). Laju Sedimen Menggunakan Metode Isotop 
210pb Di Muara Jungkat Pontianak Kalimantan Barat. Journal of Oceanography, 4(1), 48-54.

Sofian, H. O. (2010). Permasalahan Arkeologi Bawah Air Indonesia. Kapata Arkeologi, 6(11), 49-65.

Sonnenburg, E. P., \& Boyce, J. I. (2008). Data-fused digital bathymetry and side-scan sonar as a base for archaeological inventory of submerged landscapes in the Rideau Canal, Ontario, Canada. Geoarchaeology, 23(5), 654-674.

Suandi, S., Jumarang, M. I. Apriansyah, A. (2016). Analisis Pola Sirkulasi Arus di Perairan Pantai Sungai Duri Kabupaten Bengkayang Kalimantan Barat. POSITRON, 6(2), 60-71.

Sugito, S., Muliadi, M., \& Apriansyah, A. Distribusi Salinitas di Estuari Kapuas Kecil. PRISMA FISIKA, 6(2), 68-74.

Honey, M., \& Krantz, D. (2007). Global trends in coastal tourism. Center on Ecotourism and Sustainable Development.

Ardiwidjaja, R. (2017). Pelestarian Tinggalan Budaya Bawah Air: Pemanfaatan Kapal Karam sebagai Daya Tarik Wisata Selam. AMERTA, 35(2), 133-148. 